\title{
Pemanfaatan Permainan Komputer Berlisensi Free Software sebagai Media Pembelajaran Anti Korupsi Pada Anak
}

\author{
Rachmat Kriyantono ${ }^{1}$ \\ Jurusan Ilmu Komunikasi, Universitas Brawijaya, rachmat_kr@ub.ac.id \\ Bayu Indra Pratama ${ }^{2}$ \\ Jurusan Ilmu Komunikasi, Universitas Brawijaya, bayuindrap@gmail.com
}

\begin{abstract}
Abstrak
Korupsi adalah masalah besar yang dihadapi Bangsa Indonesia. Indeks persepsi korupsi Indonesia masih relatif tinggi sehingga perlu upaya penanggulangan secara bersama, termasuk dari kalangan perguruan tinggi. Pemberantasan korupsi adalah program nasional sejalan agenda reformasi untuk menjalankan kehidupan kebangsaan yang bebas korupsi. Salah satunya adalah melalui strategi pendidikan sejak usia dini, yakni menyiapkan generasi muda sejak usia dini untuk menghindari perilaku korupsi. Karena itu, tim pengabdian masyarakat mengadakan sosialisasi dan pelatihan tentang pembelajaran anti korupsi. Kegiatan ini dikemas dalam bentuk permainan game computer sehingga sesuai dengan karakter peserta pelatihan. Pelatihan diselenggarakan di SD Dinoyo Malang dengan mengundang guru dan orang tua anak sekolah dasar di Kota Malang. Hasil pelatihan ini adalah para peserta didik mengenal korupsi dan dapat memainkan permainan game anti korupsi dengan baik. Guru-guru SD se-gugus II sudah pernah menggunakan aplikasi permainan komputer dalam proses pembelajaran di SD tersebut. Aplikasi komputer membantu dalam proses pembelajaran siswa, tetapi para guru tersebut kurang mengetahui tingkat legalitas perangkat lunak komputer yang pernah digunakan. Perlu ada program berkelanjutan dan berkala untuk meningkatkan kemampuan guru dalam menggunakan aplikasi permainan komputer. Harga permainan komputer sejenis masih relatif mahal, sehingga aplikasi permainan komputer berbasis open source software dinilai membantu para guru. Diharapkan game ini yang jika dilakukan berulang kali, nilai-nilai antikorupsi yang ada dalam kandungan game ini dapat terinternalisasi secara bertahap dalam pikiran peserta didik.
\end{abstract}

Kata Kunci: Game software, Pembelajaran anti korupsi, pengabdian masyarakat, Permainan komputer

\begin{abstract}
Corruption is a big problem facing the Indonesian people. Indonesia's corruption perception index is still relatively high, so we need joint prevention efforts, including those from universities. Corruption eradication is a national program in line with the reform agenda to run a national life free of corruption. One of them is through an education strategy from an early age, namely preparing young people from an early age to avoid corrupt behavior. Because of this, the community service team conducted socialization and training on anti-corruption learning. This activity is packaged in the form of computer game play so that it matches the character of the trainee. The training was held at SD Dinoyo Malang by inviting teachers and parents of elementary school children in Malang. The results of this training are that students are familiar with corruption and can play anti-corruption games well. Elementary school
\end{abstract}




\section{JURNAL ABDIMAS BSI}

Jurnal Pengabdian Kepada Masyarakat

teachers in group II have used computer game applications in the learning process at the elementary school. Computer applications help in the learning process of students, but the teachers do not know the level of legality of computer software that has been used. There is a need for ongoing and periodic programs to improve the ability of teachers to use computer game applications. The price of similar computer games is still relatively expensive, so open source software based computer game applications are considered to help teachers. It is hoped that this game which if done repeatedly, the anticorruption values in the contents of this game can be internalized gradually in the minds of students.

Keywords: Game software, Anti-corruption learning, community service, Computer games

\section{Pendahuluan}

Usulan pengabdian masyarakat ini merupakan tindak lanjut dari pengabdian masyarakat yang telah dilakukan pada tahun sebelumnya yang dilakukan oleh tim yang sama dengan topik penggunaan free/open source software sebagai sarana pembelajaran terhadap anak usia dini. Berdasakan hasil evaluasi tim dan peserta pengabdian kepada masyarakat tersebut merekomendasikan kegiatan sosialisasi metode pembelajaran ini dilakukan secara terusmenerus dengan mengaplikasikan program permainan komputer berbasis free/open source software yang lebih banyak dengan tema yang lebih spesifik (Kriyantono, Pratama, dan Alfira, 2014). Para peserta pengabdian kepada masyarakat juga mengharapkan pelibatan orang tua peserta didik atau guru pada jenjang pendidikan yang lebih tinggi sehingga mampu memberikan pendekatan yang lebih komprehensif dalam proses pembelajaran anak.

Secara strategis kegiatan ini dapat dikaitkan dengan agenda pencegahan korupsi. Hal ini dinilai penting karena sejalan dengan agenda reformasi untuk menjalankan kehidupan kebangsaan yang bebas korupsi (baca: Tap MPR No. XI/MPR/1998, tentang Penyelenggaraan Negara Yang Bersih Dan Bebas Korupsi, Kolusi, Dan Nepotisme). Sasaran dikonkretkan kepada pencegahan tindak korupsi sejak dini. Hal tersebut dapat diwujudkan dalam bentuk pemanfaatan free software sebagai media pembelajaran anti korupsi pada anak. Upaya ini diharapkan mampu memberikan kontribusi terhadap pendidikan anti korupsi pada anak. Penanaman pendidikan anti korupsi sejak dini akan melahirkan generasi anti korupsi sehingga mencegah tindak korupsi yang berkelanjutan. Pendidikan sejak dini merupakan bentuk pencegahan yang yang paling efektif karena usia tersebut merupakan masa emas pembentukan karakter manusia (Suyanto, 2005, 2015;

Pemanfaatan permainan komputer free software dalam pendidikan anti korupsi pada anak memberikan beberapa keuntungan. Pertama, penggunaan komputer multimedia cenderung meningkatkan pemahaman anak terhadap materi pesan disampaikan (Simonson dan Thompson,1994). Angkowo dan Kosasih (2007, h. 34) mengatakan bahwa media pembelajaran memiliki pengaruh yang penting dalam proses belajar mengajar. Keduanya menyatakan pemilihan media menentukan semangat, perhatian, dan kemampuan anak. Pemilihan media pembelajaran yang tepat dapat menunjang motivasi belajar anak. Kedua, pemanfaatan permainan komputer melahirkan suasana belajar yang menyenangkan (Soulier, h. 1988:38-39). Ketiga, permainan komputer cenderung bersifat interaktif, sehingga merangsang minat anak untuk belajar (Phillips, 1997)..

Permainan komputer masih dianggap sebagai sesuatu yang berbahaya bagi perkembangan anak (Susanto, 2006). Orang tua masih memandang permainan komputer menghambat proses belajar anak (Candra, 2006). Tidak jarang permainan komputer dianggap sebagai penyebab merosotnya prestasi anak. Pendapat ini bisa diterima karena beberapa penelitian menunjukan adanya korelasi antara penggunaan permainan komputer dengan penurunan prestasi anak. Bukti ini tidak dapat dijeneralisasi pada semua permainan 
komputer (Henry, 2010). Ada permainan komputer edukatif yang justru mendorong bahkan menunjang keinginan anak untuk belajar seperti, Gcompris, Childsplay, Rapid Typing, Tux Paint, TuxMath, dan TuxTyping.. Bahkan bebeberapa perangkat lunak komputer telah dimanfaatkan untuk pendidikan anti korupsi pada anak. Tangkap Koruptor, Andai Aku Koruptor, Dilarang Bolos Sekolah, Pejuang Indonesia merupakan beberapa permainan komputer berlisensi free software yang menjadi media kampanye anti korupsi.

Pendidikan anti korupsi kepada anak melalui pemanfaatan free software juga menguntungkan kampanye anti korupsi. Pertama, upaya pencegahan korupsi di Indonesia cenderung minim. Hal yang menonjol yakni tindakan hukum dengan melakukan upaya hukum terhadap para pelaku korupsi (Darto, 2012). Kedua, mengenalkan dan melatih anak untuk menggunakan perangkat lunak yang legal (Purbo, 2001). Mendidik anak menggunakan perangkat lunak komputer bajakan atau ilegal sama seperti mengajarkan anak untuk mencuri. Tindakan mencuri merupakan esensi dari perilaku korupsi. Ketiga, penggunaan permainan komputer berlisensi free software mengurangi biaya kampanye anti korupsi karena upaya pencegahan korupsi harus dilakukan secara massif sehingga membutuhkan dana yang besar. Permainan komputer berlisensi free software bersifat gratis sehingga mudah untuk disebarkan tanpa harus membayar hak penggunaan atau penggandaan kepada pemegang hak cipta.

Berdasarkan pemikiran tersebut maka dianggap perlu untuk melakukan pelatihan kepada masyarakat tentang pemanfaatan permainan komputer berlisensi free software sebagai media pembelajaran anti korupsi pada anak. Kegiatan ini menjadikan guru dan orang tua sebagai objek sosialisasi. Keduanya dipilih karena orang tua dan guru merupakan pihak yang terdekat dengan anak dalam mensosialisikan norma dan nilai (Swartz, 2002, h. 28; Halpern dan Figuieras (2004). Lebih lanjut Santrock (2006, h. 40) menjelaskan orang tua merupakan faktor utama yang berpengaruh terhadap karakter anak. Hal tersebut yang kemudian dilengkapi dengan sikap keterbukaan, suportif, penuh kasih sayang, saling menghargai, serta konsisten dari guru sehingga membentuk pribadi anak yang baik (Berkowitz, 2002).

Berdasarkan pendahuluan, maka tim pengabdian kepada masyarakat mengidentifikasi masalah-masalah yang dihadapi oleh peserta pengabdian masyarakat antara lain:

1. Kampanye anti korupsi perlu dilakukan pada anak usia dini.

2. Penanganan perbuatan korupsi cenderung bersifat represif serta kurang memberikan perhatian kepada tindakan-tindakan preventif.

3. Peluang pemanfaatan permainan komputer berlisensi free software sebagai media pembelajaran anti korupsi pada anak.

Untuk mengatasi masalah-masalah tersebut, maka tim pengabdian kepada masyarakat menyusun tujuan yang diharapkan dapat memberikan pengetahuan metode pembelajaran dengan pemanfaatan permainan komputer berlisensi free software sebagai media pembelajaran anti korupsi pada anak dan mendorong pemanfaatan permainan komputer berlisensi free software sebagai media pembelajaran anti korupsi pada anak.

Kegiatan ini diharapkan mampu mencapai target yang ditetapkan, yakni orang tua dan guru mengetahui manfaat permainan komputer berlisensi free software sebagai media pembelajaran anti korupsi pada anak. Selain itu, orang tua dan guru mampu menggunakan pemanfaatan permainan komputer berlisensi free software sebagai media pembelajaran anti korupsi pada anak. 
Jurnal Pengabdian Kepada Masyarakat

\section{Metode}

Kegiatan ini merupakan acara sosialiasai dan workshop pemanfaatan permainan komputer berlisensi free software sebagai media pembelajaran anti korupsi pada anak kepada guru dan orang tua anak sekolah dasar di Kota Malang. Pelaksanaan kegiatan ini dilakukan di SDN Dinoyo Kota Malang.

Media pembelajaran memiliki peran penting dalam proses belajar-mengajar. Ia merupakan sarana transfer of knowledge, sehingga penting untuk memberikan perhatian kepada hal ini. Tepat atau tidaknya penggunaan metode pembelajaran menentukan hasil pembelajaran yang diperoleh. Hal ini menuntunt proses pembelajaran yang menarik agar menarik minat peserta didik untuk belajar. Penggunaan teknologi informasi dan komunikasi khususnya teknologi perangkat komputer dapat menjadi pilihan untuk mendukung proses belajar-mengajar. Keunggulan audio-visual yang dimiliki memberikan pilihan penyampaian pesan lebih menarik. Interaktifitas yang dihadirkan perangkat lunak komputer juga menjadi daya tarik minat belajar peserta didik.

Pemikiran tersebut mengantarkan perlu adanya usaha untuk menyosialisasikan pemanfaatan komputer sebagai metode pembelajaran. Penggunaan aplikasi komputer membuat proses pembelajaran menjadi lebih menarik. Peserta didik tidak hanya belajar menggunakan cara konvensional seperti mengingat dan mengulang melainkan juga dengan bermain. Permainan yang diberikan bersifat interaktif sehingga proses belajar lebih menarik. Pesan multimedia yang ditampilkan melalui komputer diharapkan mampu menarik minat belajar anak. Penggunaan aplikasi permainan komputer berbasis open free software juga diharapkan mampu mengatasi mahalnya harga perangkat lunak komputer edukatif. Peningkatan pengetahuan masyarakat mengurangi kecemasan orang tua guru terhadap penurunan prestasi anak akibat permainan komputer.

Pendidikan anti korupsi kepada anak melalui pemanfaatan free software juga menguntungkan kampanye anti korupsi. Pertama, upaya pencegahan korupsi di Indonesia cenderung minim. Hal yang menonjol yakni tindakan hukum dengan melakukan upaya hukum terhadap para pelaku korupsi (Darto, 2012). Kedua, mengenalkan dan melatih anak untuk menggunakan perangkat lunak yang legal (Purbo, 2001). Mendidik anak menggunakan perangkat lunak komputer bajakan atau ilegal sama seperti mengajarkan anak untuk mencuri. Tindakan mencuri merupakan esensi dari perilaku korupsi. Ketiga, penggunaan permainan komputer berlisensi free software mengurangi biaya kampanye anti korupsi karena upaya pencegahan korupsi harus dilakukan secara massif sehingga membutuhkan dana yang besar. Permainan komputer berlisensi free software bersifat gratis sehingga mudah untuk disebarkan tanpa harus membayar hak penggunaan atau penggandaan kepada pemegang hak cipta.

Berdasarkan analisis permasalahan yang ada, maka tim pengabdian masyarakat melihat perlu adanya mengembangkan penggunaan media pembelajaran orang tua dan pendidik sekolah dasar terhadap anak. Tim pengabdian masyarakat berupaya meningkatkan pengetahuan dan pemanfaatan teknologi informasi dan komunikasi berbasis komputer sebagai sarana pembelajaran. Proses peningkatan 
tersebut dilakukan dengan menyosialisasikan pemanfaatan permainan komputer berlisensi free software sebagai media pembelajaran anti korupsi pada anak.

Proses ini dilakukan dengan mengundang orang tua wali dan guru-guru sekolah dasar. Tim pengabdian masyarakat akan memberikan pengetahuan pemanfaatan permainan komputer berlisensi free software sebagai media pembelajaran anti korupsi pada anak. Kemudian tim akan memberikan cara penggunaan aplikasi permainan komputer berbasis free software sebagai media pembelajaran anak usia sekolah dasar.

Materi-materi yang disampaikan dalam sosialisasi diharapkan mampu menjadi jawaban masalah yang dihadapi oleh orang tua wali dan pendidik sekolah dasar. Penggunaan aplikasi komputer membuat proses pembelajaran anti korupsi menjadi lebih menarik. Peserta didik tidak hanya belajar menggunakan cara konvensional seperti mengingat dan mengulang melainkan juga dengan bermain. Permainan yang diberikan bersifat interaktif sehingga proses belajar lebih menarik. Pesan multimedia yang ditampilkan melalui komputer diharapkan mampu menarik minat belajar anak. Penggunaan aplikasi permainan komputer berbasis free software juga diharapkan mampu mengatasi mahalnya harga perangkat lunak komputer edukatif. Peningkatan pengetahuan masyarakat mengurangi kecemasan orang tua guru terhadap penurunan prestasi anak akibat permainan komputer.

Khalayak sasaran pada kegiatan ini adalah para orang tua dan pendidik anak usia sekolah dasar di Kota Malang. Keterbatasan sumber daya yang ada mendorong tidak semua orang tua dan pendidik anak usia sekolah dasar di Kota Malang yang diundang dalam kegiatan ini. Peserta kegiatan ini dibatasi hanya 20 orang yang terdiri dari 10 orang tua anak dan 10 pendidik anak usia sekolah dasar yang berasal dari 5 sekolah dasar terpilih di Kota Malang. Selain itu, kegiatan ini adalah suatu bentuk kegiatan yang bersifat pilot-project yang dimungkinkan dikembangkan dalam lingkup yang lebih luas sebagai tindak lanjut kegiatan sekarang ini.

Pelaksanan pelatihan pemanfaatan permainan komputer berlisensi free software sebagai media pembelajaran anti korupsi pada anak dilaksanakan dalam satu hari. Diharapkan dalam waktu satu hari ini, tujuan pengabdian masyarakat dapat tercapai. Tim memandang bisa dilakukan kegiatan tindak lanjut untuk kegiatan pengabdian masyarakat di masa berikutnya.

Perencanaan telah disusun secara sistematis dalam tabel sebagai berikut:

SOSIALISASI \& WORKSHOP

\begin{tabular}{|l|l|l|l|}
\hline No & Waktu & Acara & Petugas/Pemateri \\
\hline 1 & $08.30-09.00$ & $\begin{array}{l}\text { Registrasi, pemberian bahan materi, } \\
\text { coffee break }\end{array}$ & Panitia \\
\hline 2 & $09.00-10.30$ & $\begin{array}{l}\text { Pendidikan Anti Korupsi } \\
\text { Pengabdian } \\
\text { Masyarakat }\end{array}$ \\
\hline 3 & $10.30-12.00$ & $\begin{array}{l}\text { Pemanfaatan permainan komputer } \\
\text { berlisensi free software sebagai media } \\
\text { pembelajaran anti korupsi pada anak }\end{array}$ & Rachmat Kriyantono \\
\hline
\end{tabular}


Jurnal Pengabdian Kepada Masyarakat

\begin{tabular}{|l|l|l|l|}
\hline 4 & $12.00-13.00$ & Istirahat, Sholat, dan Makan & Panitia \\
\hline 5 & $13.00-14.30$ & $\begin{array}{l}\text { Aplikasi permainan komputer berlisensi } \\
\text { free software sebagai media pembelajaran } \\
\text { anti korupsi pada anak }\end{array}$ & Bayu Indra Pratama \\
\hline
\end{tabular}

\section{Hasil dan Pembahasan}

Kegiatan pegabdian masyarakat berbentuk pelatihan Acara ini dilaksanakan selama satu hari pada 7 September 2018 bertempat di Laboratorium Komputer SD Negeri Dinoyo 2. Jumlah peserta pada kegiatan ini berjumlah 56 orang dari Guru SD se-gugus II Kecamatan Lowokwaru Malang.

Acara dikemas dalam bentuk pelatihan yaitu dengan menghadirkan beberapa narasumber antara lain:

a. Rachmat Kriyantono, Ph.D. menyampaikan materi tentang metode pemberlajaran komunikatif.

b. Bayu Indra Pratama, M.A. menyampaikan metode pembelajaran anak usia dini dengan aplikasi permainan komputer sebagai media pembelajaran antikorupsi pada anak

Peserta mempraktikan penggunaan Aplikasi Permainan komputer Berbasis Open Source Software. Kegiatan ini sekaligus memberikan pengalaman langsung kepada guru-guru tersebut tentang cara menggunakan aplikasi komputer yang diberikan. Peserta diajak untuk menggunakan program permainan komputer seperti DilarangBolosSekolah, Farmonster, Gcompris, Install_Stykz, KaptenPembasmi, Pejuang, PemburuTikus, PetDevine, Prima, QPeriodicTable, Simutrans, TangkapKoruptor, GCompris, TuxMath, TuxType, TuxPaint, Stykz, Stellarium. DilarangBolosSekolah merupakan games yang mengajarkan agar tidak melakukan bolos sekolah. Game ini secara tidak langsung akan memengaruhi siswa mengetahui dampak dari membolos sekolah. FarmMonster adalah sebuah game yang mengjarkn tentang bahaya merokok. Game ini berisi tentang anjuran untuk membasmi monster yang sedang merokok dan mengganggu kegiatan beternak. GCompris merupakan aplikasi permainan komputer logika bagi anak usia 1-5. Aplikasi ini mengenalkan huruf, angka, bentuk, dan gambar, bagi anak-anak usia dini dalam bentuk permainan. KaptenPembasmi merupakan game yang mengajarkan untuk melawan pada tindakan kejahatan. Tujuan dari permainan ini adalah memengaruhi pola pikir siswa agar membasmi tindakan negatif dan kecurangan. RuangBeracun merupakan game yang mengajarkan anak agar tidak merokok. Pejuang adalah game berperang yang mengisahkan kisah pahlawan dalam melawan Belanda. Permainan ini dapat menumbuhkan sikap nasionalisme pada siswa. PemburuTikus merupakan game yang mengajarkan bagaimana kecerdikan untuk membasmi tikus. Tikus disini diartikan sebagai koruptor. TangkapKoruptor merupakan game yang mengajrakan sistematika dalam menangkap korupstor. TuxMath adalah permainan komputer yang mengajarkan anak-anak untuk berhitung. Teknik-teknik perkalian, pejumlahan, pengurangan, dan pembagian angaka disampaikan dalam bentuk animasi. TuxPaint memberikan kesempatan anak-anak untuk belajar mengambar dengan menggunakan keyboard dan mouse. Anak-anak dikenalkan berbagai animasi, gambar, warna, dan pola. Stykz adalah program pembelajaran animasi sederhana. Para guru ini diharapkan mampu mengajarkan peserta-peserta didik membuat animasi dalam bentuk sederhana.

Hasil sosialiasi dan workshop ditemukan bahwa guru-guru ini pernah menggunakan permainan komputer sebelumnya, tetapi belum pernah mendapatkan pelatihan penggunaan aplikasi tersebut. Berdasarakan pengakuan yang diberikan oleh salah satu pengajar SD 
Dinoyo 2 ini, ia belum mengenal aplikasi permainan komputer berbasis open source. Mereka pada umumnya mendapatkan aplikasi permainan dengan cara mengunduh dari Internet. Para guru ini tidak memperhatikan soal legalitas aplikasi yang diunduhnya. Pengenalan aplikasi permainan komputer berbasis open source software ini dianggap membantu karena harga perangkat lunak sejenis di pasaran harganya mahal. Kehadiran open source software membantu membantu para guru ini mendapatkan software yang legal secara gratis.

Guru-guru SD Dinoyo se-gugus II menganggap aplikasi permainan komputer dapat membantu proses pembelajaran. Mereka menganggap bahwa aplikasi yang disampaikan memberikan kesempatan mengenalkan materi kepada anak-anak dengan cara yang menarik. Guru-guru ini menganggap pelatihan membantu menyediakan bahan pembelajaran informasi, karena mereka kadang merasa sulit mendapatkan media sulit mendapatkan informasi. Para peserta ini mengharapkan agar acara ini dilaksanakan secara berkelanjutan dengan lebih banyak permainan serta metode yang diberikan. Guru-guru Sekolah Dasar ini berharap dapat meningkatkan kemampuan menggunakan aplikasi permainan untuk mendorong ketertarikan peserta didik dalam belajar.

\section{Media Pembelajaran}

Proses belajar mengajar merupakan salah satu proses terpenting dalam kehidupan manusia. Anak-anak memulai usia belajar sejak berada pada kisaran usia 3-4 tahun dan terus berlanjut hingga memasuki perguruan tinggi. Masa pembelajaran di tingkat dasar yaitu pada Pendidikan Anak Usia Dini (PAUD), Taman Kanak-kanak (TK) dan Sekolah Dasar (SD) merupakan salah satu masa terpenting. Hal itu karena pada masa tersebut anak-anak tidak hanya sedang belajar membaca, menulis atau ilmu pengetahuan dasar, melainkan juga proses mengenal diri sendiri dan lingkungannya (Santoso, 2004). Oleh karena itu peran guru di sekolah sangatlah penting. Selain menampilkan keteladanan perilaku-perilaku baik kepada para anak para orang tua (Swartz, 2002) dan guru juga dituntut mampu menghadirkan suasana belajar yang positif (Berkowitz, 2002) Situasi ini memungkinkan anak menyerap dengan baik ilmu yang diajarkan(DePorter dan Hernacki, 2001).

Proses belajar-mengajar merupakan salah satu bagian dari proses komunikasi (Yusuf, 1990). Proses komunikasi selalu membutuhkan saluran untuk menyampaikan pesan dari pengirim pesan (komunikator) menuju penerima pesan (komunikan). Begitu juga dengan proses pembelajaran. Setiap proses pembelajaran membutuhkan saluran komunikasi, yang kemudian lazim disebut sebagai media pembelajaran. Media pembelajaran sendiri menurut Munadi (2010, h. 7) adalah segala sesuatu yang dapat dimanfaatkan dan menyampaikan pesan dari sumber secara terencana agar tercipta kondisi belajar yang mendukung melakukan proses belajar-mengajar secara efektid dan efisien. Kustandi \& Sutjipto (2011, h. 9) memahaminya sebagai sebuat bantu penyampaian pesan dalam proses belajar mengajar. Arsyad (2011, h. 3) kemudian merumuskan lebih khusus bahwa media pembelajar merupakan perangkat-perangkat atau alat yang digunakan dalam menyampaikan materi pembelajaran dalam bentuk teks, grafis, suara, maupun audio visual.

Pemilihan media pembelajaran yang tepat akan sangat membantu keberhasilan proses pembelajaran (Angkowo dan Kosasih, 2007, h. 34). Tak jarang dalam proses pembelajaran baik di sekolah maupun di perguruan tinggi, para anak merasa kesulitan memahami isi materi yang disampaikan di kelas atau misalnya kehilangan konsentrasi selama proses belajar di kelas. Hal inilah yang membuat para pendidik perlu mempertimbangkan penggunaan media pembelajaran yang sesuai dengan kebutuhan dan kondisi peserta didiknya (Susilana, 2009).

Media pembelajaran yang baik akan sangat membantu efisiensi dan efektivitas proses belajar mengajar dan membantu konsentrasi peserta didik dalam menyerap materi pelajaran (Angkowo dan Kosasih, 2007). Untuk memilih media pembelajaran yang tepat, para pendidik 
perlu mempertimbangkan kondisi, ketertarikan dan kebutuhan peserta didik (Susilana, 2009). Seperti misalnya apakah kecenderungan minat mereka untuk bisa menyerap materi melalui komunikasi lisan atau membutuhkan fasilitas media audio-visual. Tak jarang pada proses belajar mengajar para peserta didik merasa kehilangan konsentrasi karena mengantuk atau berbicara dengan teman-temannya karena merasa bosan. Hal-hal inilah yang membuat para pendidik harus cermat dalam memperhatikan situasi kelas dan para peserta didik.

Haryono menyebutkan terdapat 4 macam media pembelajaran antara lain (a) Media Visual : grafik, diagram, chart, bagan, poster, kartun, komik; (b) Media Audial : radio, tape recorder, laboratorium bahasa, dan sejenisnya; (c) Projected still media : slide; over head projektor $(\mathrm{OHP})$, in focus dan sejenisnya; (d) Projected motion media : film, televisi, video (VCD, DVD, VTR), komputer dan sejenisnya. (http://belajarpsikologi.com/pengertianmedia-pembelajaran/ diakses 1 Mei 2015). Para pendidik perlu mengenal beberapa kondisi untuk bisa memilih media pembelajaran yang sesuai. Strauss dan Frost mengidentifikasi sembilan faktor kunci yang harus menjadi pertimbangan dalam memilih media pembelajaran (http://eprints.uny.ac.id/8198/3/BAB\%202\%20-\%2008513241018.pdf). Kesembilan faktor kunci tersebut antara lain batasan sumber daya institusional, kesesuaian media dengan mata pelajaran yang diajarkan, karakteristik anak atau anak didik, perilaku pendidik dan tingkat keterampilannya, sasaran pembelajaran mata pelajaran, hubungan pembelajaran, lokasi pembelajaran, waktu dan tingkat keragaman media.

Untuk faktor pertama yaitu batasan sumber daya institusional, tidak bisa dipungkiri bahwa institusi pendidikan bisa memiliki keterbatasan sumber daya, baik itu sumber daya finansial, teknologi, keterbatasan jumlah pendidik, dan sebagainya (Susilana, 2009). Untuk itulah para pendidik perlu memperhatikan kondisi dimana proses belajar-mengajar berlangsung. Para pendidik bisa memilih media pembelajaran yang tepat sesuai dengan kondisi institusi dimana proses belajar-mengajar berlangsung (Angkowo dan Kosasih, 2007). Faktor kedua yaitu kesesuaian media dengan mata pelajaran yang diajarkan. Beberapa mata pelajaran mensyaratkan keterampilan khusus, seperti misalnya matematika dengan kemampuan berhitung, mata pelajaran ilmu alam dengan kemampuan praktikum. Tujuan pembelajaran yang ingin dicapai (learning outcome) inilah yang perlu diperhatikan dalam memilih media pembelajaran.

Faktor ketiga yaitu karakteristik anak atau anak didik, khususnya dalam hal ini bisa dikaitkan dengan karakteristik tipe belajar (Angkowo dan Kosasih, 2007). Terdapat setidaknya tipe belajar yaitu tipe belajar audio, visual dan kinesika. Para peserta didik dengan tipe belajar audio akan lebih nyaman untuk belajar dengan mendengarkan, baik itu mendengarkan ceramah guru di depan kelas atau melalui rekaman suara. Mereka juga membutuhkan ketenangan dalam proses belajar sehingga suara yang dirasa mengganggu bisa menghilangkan konsentrasi mereka. Sementara itu, tipe visual lebih menyukai proses belajar secara visual misalnya dengan membaca. Mereka mampu merekam lebih banyak hal melalui membaca dan melihat. Tipe kinesika membutuhkan belajar sambil bergerak, misalnya mereka akan sambil menulis ketika mendengarkan atau ketika membaca. Hal-hal seperti itu dirasa mampu meningkatkan daya ingat lebih daripada ketika mereka hanya sekedar mendengarkan atau membaca saja.

Dengan mengenali tipe belajar para peserta didik, para pendidik diharapkan mampu untuk lebih selektif dalam memilihkan media pembelajaran yang tepat untuk pelaksanaan proses belajar mengajar (Angkowo dan Kosasih, 2007). Misalnya para pendidik bisa memilih medium audio-visual yang dirasa sesuai baik untuk peserta didik dengan tipe belajar audio maupun visual. Tak dapat dipungkiri bahwa materi yang bersifat audio-visual seringkali lebih mudah diterima dan direkam dalam ingatan. Media pembelajaran yang tepat dengan kondisi 
dan kebutuhan peserta didik akan lebih mampu menyampaikan pesan dengan efektif dan mudah diterima oleh peserta didik.

Selain tipe belajar, faktor selanjutnya yaitu perilaku pendidik dan tingkat keterampilannya. Para pendidik tidak hanya seorang pengajar yang bertugas menyampaikan ilmu pengetahuan di kelas, tetapi juga seorang teladan bagi para peserta didik. Para peserta didik akan mengamati seperti apa perilaku pengajar mereka dan kemudian menyerap nilainilai yang mereka pelajari darinya (Angkowo dan Kosasih, 2007). Para pengajar juga perlu memperhatikan karakteristik keterampilan dirinya dalam proses pengajaran, misalnya apakah ia tergolong pengajar yang mampu menyampaikan materi dengan baik secara audio atau misalnya secara visual misalnya dengan bantuan media gambar, foto, grafik, dan sebagainya.

Faktor selanjutnya yaitu sasaran pembelajaran mata pelajaran. Sebagaimana disinggung diatas bahwa proses pembelajaran selalu mensyaratkan capaian belajar atau learning outcome tertentu. Dan karena itulah media pembelajaran perlu disesuaikan dengan learning outcome yang ingin dicapai. Faktor selanjutnya yaitu hubungan pembelajaran, lokasi pembelajaran, waktu dan tingkat keragaman media (Angkowo dan Kosasih, 2007). Pemilihan media pembelajaran perlu disesuaikan dengan lokasi, waktu dan tingkat keragaman media yang bisa diakses.

\section{Perangkat Lunak Komputer Sebagai Media Pembelajaran Anti Korupsi}

Proses belajar-mengajar kini semakin menyadari arti penting penggunaan teknologi untuk membantu pelaksanaan dan upaya pencapaian tujuan-tujuannya. Saat ini tidak sedikit sekolah yang telah menyediakan fasilitas teknologi komputer dalam wujud laboratorium komputer bahkan di tingkat pendidikan untuk anak usia taman kanak-kanak. Laboratorium komputer dimaksudkan untuk membantu anak belajar memanfaatkan teknologi serta membuat proses belajar menjadi lebih mudah dan menyenangkan ((Berkowitz, 2002; Angkowo dan Kosasih, 2007).

Namun sayangnya hal tersebut belum secara optimal dipahami oleh elemen-elemen yang terkait dengan proses pembelajaran khususnya guru dan orang tua. Laboratorium komputer belum semuanya optimal digunakan untuk membantu mengenalkan cara-cara belajar yang efektif dan menyenangkan. Demikian juga halnya dengan penggunaan komputer di rumah bagi anak-anak. Orang tua cenderung memahami bahwa komputer adalah perangkat yang digunakan untuk melakukan fungsi-fungsi kerja seperti mengetik atau fungsi permainan saja. Hal ini juga berimbas pada penilaian bahwa komputer bisa memberikan efek negatif bagi anak-anak karena anak-anak belum mampu menggunakan komputer dalam fungsi kerja sehingga mereka hanya akan menggunakan fasilitas permainan (game) yang ada di dalamnya.

Padahal perangkat lunak komputer juga dapat menjadi sarana pembelajaran anti bagi anak. Melalui berbagai game permainan, anak dapat diajarkan tentang nilai-nilai anti korupsi. Komisi Pemberantasan Korupsi sendiri telah meluncurkan permainan anti korupsi berjudul "Semua Bisa Ber-AKSI" dan "Sahabat Pemberani: Permainan Kejujuran" (baca:http://tekno.kompas.com/read/2014/12/10/09030097/kpk.rilis.dua.game.anti.korup si diakses pada 1 Juni 2014). Permainan-permainan serupa juga coba dikembangkan oleh komunitas-komunitas anti korupsi. Divine Game salah satu pengembang di Indonesia juga membagikan permainan-permainan komputer dengan tema anti korupsi secara gratis. Melalui situs http://www.divinekids.com, David Setiabudi, pemilik sekaligus pengembang Divine Game membagikan berbagai permainan komputer anti korupsi seperti, Tangkap Koruptor, Andai Aku Koruptor, Dilarang Bolos Sekolah, Pejuang Indonesia. Bahkan Partai 
Jurnal Pengabdian Kepada Masyarakat

Demokrat melakukan kampanye anti korupsi pada 2009 melalui permainan komputer, SBY Vs Korupsi.

\section{Simpulan dan Rekomendasi}

Dari kegiatan yang telah dilakukan, dapat disimpulkan bahwa guru-guru SD segugus II sudah pernah menggunakan aplikasi permainan komputer dalam proses pembelajaran di SD tersebut. Aplikasi komputer membantu dalam proses pembelajaran siswa, tetapi para guru tersebut kurang mengetahui tingkat legalitas perangkat lunak komputer yang pernah digunakan. Perlu ada program berkelanjutan dan berkala untuk meningkatkan kemampuan guru dalam menggunakan aplikasi permainan komputer. Harga permainan komputer sejenis masih relatif mahal, sehingga aplikasi permainan komputer berbasis open source software dinilai membantu para guru.

Kegiatan sosialisasi metode pembelajaran ini perlu dilakukan secara terusmenerus dengan mengaplikasikan program permainan komputer berbasis open source software yang lebih banyak. Kegiatan ini diharapkan melibatkan orang tua peserta didik sehingga mampu memberikan pendekatan yang lebih komprehensif dalam proses pembelajaran anak. Workshop akan meliputi berbagai tingkat kesulitan dan jenis permainan sehingga dapat menyediakan aplikasi yang sesuai dengan tingkat kemampuan dan kebutuhan siswa.

\section{Acknowledgements}

Terima kasih kepada Fakultas Ilmu Sosial \& Ilmu Politik Universitas Brawijaya atas dukungan dana untuk kegiatan pengabdian kepada masyarakat ini.

\section{Daftar Pustaka}

Angkowo, R., dan Kosasih, A. (2007). Optimalisasi media pembelajaran. Jakarta : PT. Grasindo

Arsyad, A. (2011). Media pembelajaran. Jakarta: PT Raja Grafindo Persada.

Chandra, A. N. (2006). Gambaran perilaku dan motivasi pemain online games. Jurnal Pendidikan Penabur, 7(5), 1-10.

Darto, M. (2012). Percepatan dan pemberantasan korupsi, realitis, atau utopis?. Jurnal Borneo Administrator, 8(2).

DePorter, Bobbi dan Hernacki, M. (2001). Quantum Learning:Membiasakan belajar nyaman dan menyenangkan. Bandung: Kaifa.

Halpern, R., \& Fiqueiras, A. C. M. (2004). Environmental influences on child mental health. Journal de Peditria, vol. 80 (2), 104-110.

Henry, S. (2010). Cerdas dengan Game. PT Gramedia Pustaka Utama.

Kustandi, C., dan Sutjipto, B. (2011). Media pembelajaran: manual dan digital. Bogor: Ghalia

Kriyantono, R., Pratama, B.I.,dan Alfira, N. (2014) Laporan Pengabdian Masyarakat Metode Pembelajaran Anak Usia Dini dengan Aplikasi Permainan Komputer Berbasis Open Source Software Tahun 2014. Univeritas Brawijaya: Tidak diterbitkan. 
Munadi, Y.. (2008). Media Pembelajaran:suatu pendekatan baru. Jakarta: Gaung Persada Pers

Tap MPR No. XI/MPR/1998, tentang Penyelenggaraan Negara Yang Bersih Dan Bebas Korupsi, Kolusi, Dan Nepotisme

Phillips, R. (1997). The Developer's Handbook to Interactive Multimedia, London: Kogan Page.

Purbo, O. W. (2001) Apa Susahnya Tidak Membajak Software?. diambil dari: http://www. kompas. com/kompas-cetak/0103/06/iptek/apas40. htm. Diakses 1 Juni 2015

Santoso, S. (2004) Pendidikan anak usia dini. Jakarta: Citra Pendidikan

Simonson, M.R. dan Thompson. (1994). Educational computing foundations (Second ed.). Columbus : Meril.

Soulier, J. (1988). The design and development of computer based instruction. London : Allyn and Bacon, Inc.

Suyanto, S. (2005). Dasar-dasar pendidikan anak usia dini. Yogyakarta: Hikayat Publishing.

Suyanto, S. (2015). Pendidikan karakter untuk anak usia dini. Jurnal Pendidikan Anak, Volume 1, Edisi 1, Juni 2012

Susanto, H. (2006). Mengembangkan kemampuan self regulation untuk meningkatkan keberhasilan akademik anak. Jurnal Pendidikan Penabur, 7, 64-71.

Susilana, R., Si, M., \& Riyana, C. (2009). Media pembelajaran: hakikat, pengembangan, pemanfaatan, dan penilaian. CV. Wacana Prima.

Swartz, A. J. (2002). Transmitting moral wisdom in an age of the autonomous self. dalam Damon, W. Bridging in a New Era in Character Education. USA : Hoover Institution Press

Yusuf, P. (1990) Komunikasi pendidikan dan komunikasi intrusional. Bandung: Remaja Rosdakarya 
Jurnal Pengabdian Kepada Masyarakat

Lampiran

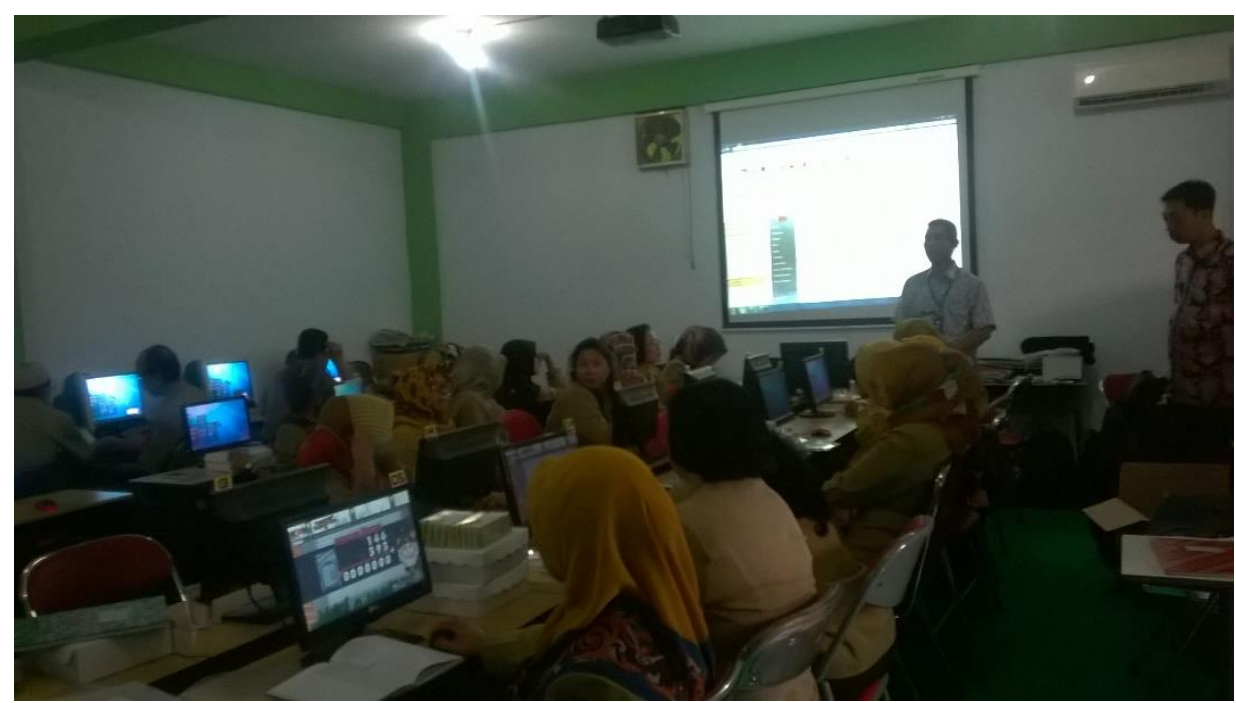

Foto 1. Rachmat Kriyantono, Ph.D. membuka acara pengabdian Masyarakat.

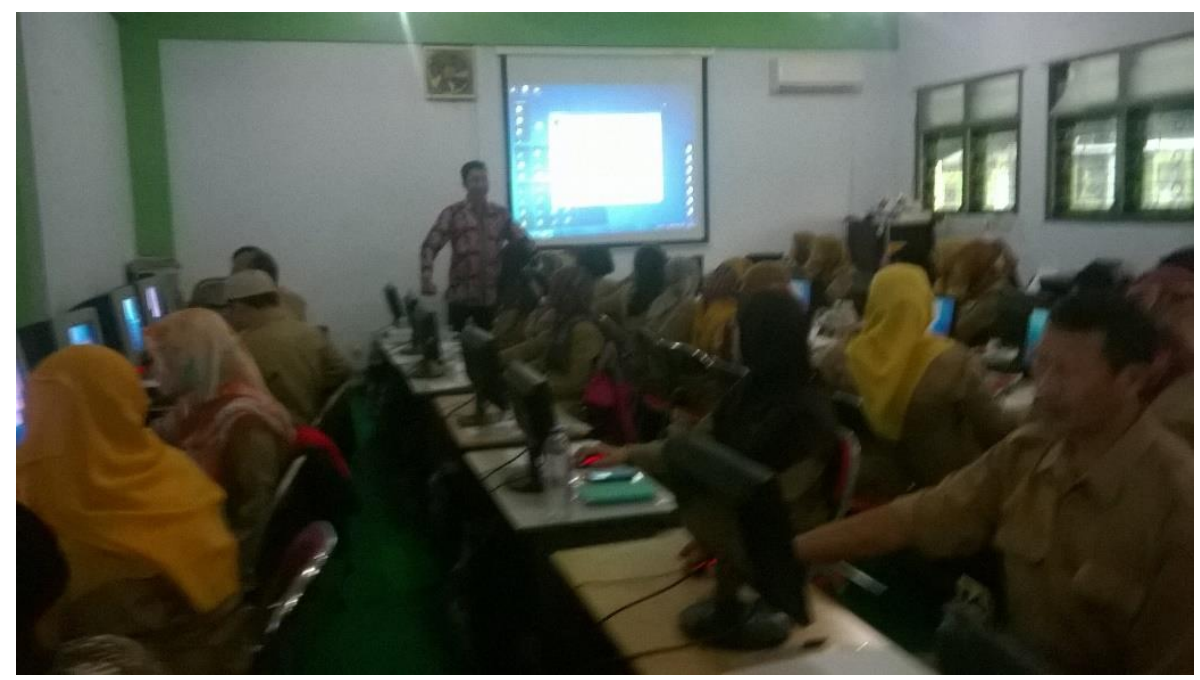

Foto 2. Bayu Indra Pratama, M.A. memberikan materi tentang penggunaan perangkat lunak komputer untuk tujuan antikorupsi 
Jurnal Pengabdian Kepada Masyarakat

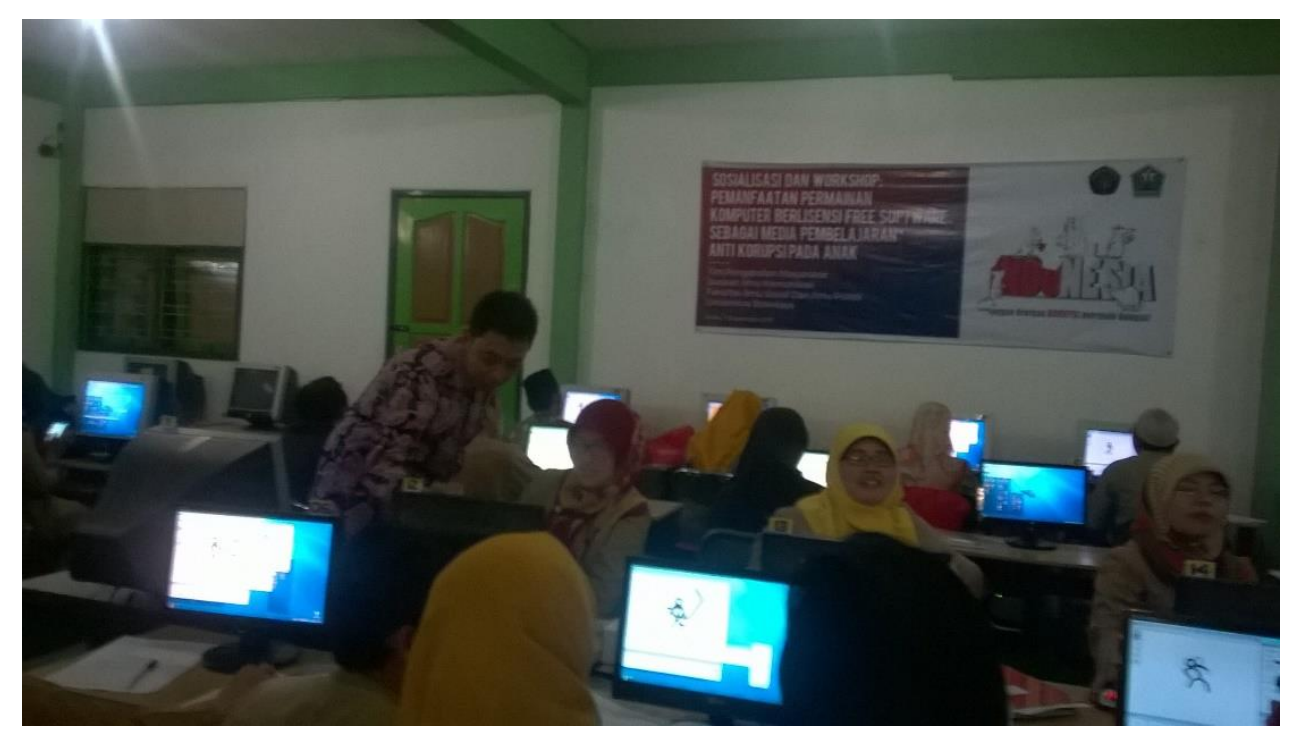

Foto 3. Menjadi tutor para peserta dalam menggunakan perangkat lunak komputer

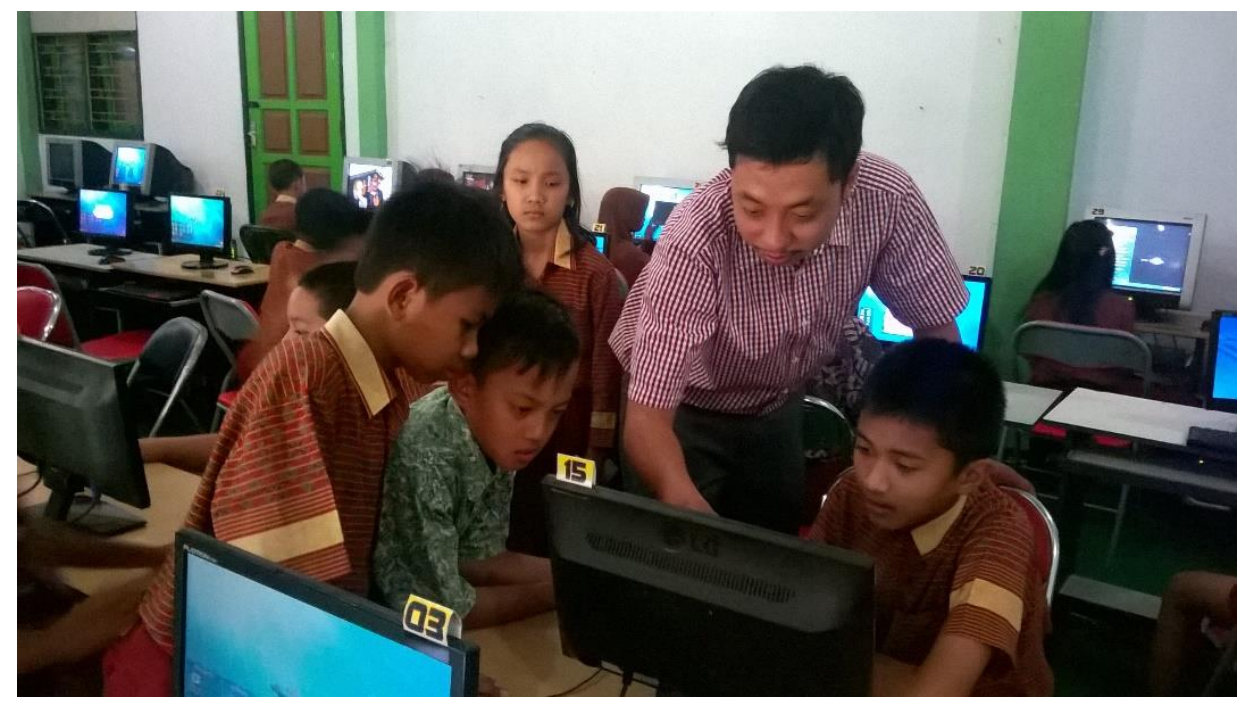

Foto 4. Melakukan pendampingan pada siswa SD pasca pengabdian masyarakat 